\title{
Volkskuns en fin de siècle: Perspektiewe op parallelle tendense in die Vlaamse en Afrikaanse prosa
}

\begin{abstract}
In nineteenth century Europe, the fin de siecle was in a literay sense characterized by the aesthetic cult, Symbolism, and a decadent mood. However, the traditional historians of Flemish and Afrikaans literature accentuate the mild romanticism and realism as typical of what have since become, for a corresponding period ( $\pm 1895-1925$ ), in both those literatures their canonized texts. Literary history also identifies in Flemish and Afrikaans prose a definite striving towards a 'national' literature, thus reflecting the nationalistic political and cultural movements of those early times.

This article focusses on a few, but interesting deviations from that established pattern. It reveals that, especially in works of prose written by surprisingly many of those authors (who were often identified with a 'national' cause), some marked tendencies of the decadent fin de siecle are clearly present.

A contextual rereading of these texts - which even now are either completely under-estimated or ignored by conventional literary history - may bring about a re-evaluation of the existing canon of early Flemish and Afrikaans prose.
\end{abstract}

\section{Inleidend}

Om volkskuns en fin de siècle, twee sulke paradoksale en opponerende begrippe, bymekaar te plaas en samevattend te bespreek, is dalk 'n paradoks geskik vir hierdie negentigerjare van die twintigste eeu. Daar heers nou weer 'n einde-van-die-eeu era, 'n millenium selfs, en soos Fletcher (1979:17) tereg spekuleer: "Something about round numbers, and the terror of turning centuries, encourages the equation: when better to discern an apocalypse, or begin a secular 'new age'?". Maar moenie vergeet nie, reeds die eeu wat die geboorte van Christus voorafgegaan het, is só deur 'n pessimistiese Lucretius beskryf: "And now already our age is decayed, everything slowly decays, marching towards the tomb, exhausted by the ancient lapse of time" (aangehaal in Gilman, 1979:41). 'n Kulturele bewussyn - en daarom ook 'n letterkunde deurspek met motiewe - van ondergang en verval, is dus klaarblyklik nie uniek aan net die einde van die negentiende eeu in Europa nie. Die fin de siecle-mentaliteit word deur skrywers en lesers in verskillende eras en areas ervaar en gekommunikeer.

'n Ander herhalende verskynsel is dat gedurende tydperke van staatkundige en maatskaplike onsekerheid en omwentelinge, die groter en formele sosio-kulturele strukture soos 
onder andere politieke bewegings, kultuurliggame, die uitgewersbedryf, maar ook die kanoniserende literêre geskiedskrywing, die kritiek én baie lesers, geredelik 'n 'opheffende' en 'stabiliserende' letterkunde sal propageer en sanksioneer. Met ander woorde, binne 'n bedreigende politieke en kulturele atmosfeer word daar sterker gefokus op die beskermende bolwerk van 'n idealiserende, sogenaamde representatiewe literatuur, 'n nasionale letterkunde, volkskuns inderdaad. Binne so 'n tradisionele konteks van bevestigende en reeds geykte perspektiewe op die maatskappy en die kultuur, staan die ontnugterende skeptisisme wat saamgaan met 'n meestal individuele erkenning van onstuitbare veranderinge, verval en ondergang, in skerper reliëf. Die fin de siècle-sfeer, soos veral op literêre wyse gemanifesteer in 'n dekadente stemming en styl, gedy daarom juis, op paradoksale wyse, binne die omringende ruimte van 'n behoudende 'kuns vir en van die volk'.

Dit behoort nie te moeilik te wees om hierdie opponerende verskynsels in ons eie vloeibare tydgewrig op te merk nie. Selfs die terloopse waarnemer raak bewus van tydgenootlike gebeure en kommentaar waardeur of die terugkeer na bekende ideale en konvensies, of die uitreik na simplistiese en gerusstellende lewensvorme en beskouinge onder andere hiér, in Europa en in die VSA bepleit en verabsoluteer word. Daar is in Oos-Europa die engnasionalistiese bewegings wat volg op radikale staatkundige veranderinge; 'n "Vlaams Blok"-party wat vreemdelinge en vreemde dinge in België afweer; die Amerikaanse Time met entoesiastiese hoofartikels oor "The simple life comes back" (Castro, 1991:44-47); 'n Nasionale leeskringkongres in Suid-Afrika (Welkom, Oktober 1991) waartydens koerantredakteurs, uitgewers én skrywers maan dat net 'boeke vir die volk' geskryf behoort en gepubliseer sal word; selfs byderwetse 'dames'-tydskrifte waarin die mite van die geluksalige huisvrou en moeder opportunisties van nuuts af opgebou word. Dit alles is slegs enkele fasette van die hedendaagse veelsydige spektrum, waarbinne tydens 'n era van transformasie en ondergang, die sug na 'n gerusstellende volkskuns én die bewussyn van 'n onafwendbare fin de siècle saambestaan (vergelyk die hoofartikel oor "The year 2000" in Time, Grunwald, 1992:57-60). Dit kan waarskynlik sinvol wees om 'n soortgelyke situasie tydens 'n ooreenstemmende tydperk te beskou. Om te kyk of en hóé die Europese fin de siècle van die negentiende eeu wel in die vroeë Vlaamse en Afrikaanse prosa gemanifesteer is - twee literêre gebiede wat primêr met 'n nasionale letterkunde en 'n konserwatiewe volkskuns vereenselwig word - is dus die doel van my hieropvolgende ondersoek.

\section{Begripsomskrywing}

Met inagneming van die subjektiewe, relativerende en steeds veranderlike wyse waarop kultuurbegrippe meestal hanteer word, is 'n termdefinisie binne die konteks van hierdie artikel, tog nodig.

\subsection{Die term fin de siecle}

Die term fin de siècle, verwysende na 'n 'einde-van-die-eeu'-bewussyn, slaan op die kulturele sfeer spesifiek eie aan die laat negentiende-eeuse Europa (sowel op die vasteland as in Engeland). Van besondere belang is die literêre vormgewing daarvan tydens die jare \pm 1860 -1914 - 'n periode van groot sosio-kulturele veranderinge - en hoe dit sigbaar geword het in kunsstrominge soos die Naturalisme en die Simbolisme, maar boweal in ' $n$ tendens tot die dekadentisme. Ten opsigte van laasgenoemde begrip funksioneer die betekenis van sowel oorryp as steriel; 'n paradoksaliteit wat deur die literêre prosa verder verruim word in 
verhale met beskrywings en situasies van ondergang en transformasie, in handelinge gemotiveer deur ekstreme wellus en kille afsydigheid, en deur 'n aksent op sowel artifisiële en eksotiese oordaad as beelde van verval. Die dekadente werk vertolk die somberste en die mees uitspattige emosies; in vertellings word bepaalde kleure (groen, pers), blomme (die orgidee en lelie), en motiewe (die Salome-beeld, Wagner-musiek, 'n verlammende letargie én koorsagtige obsessies) beklemtoon. Uitsonderlike karaktertipes soos die dandy, die homme fatale en femme fatale, androgienes en wanstaltige figure tree op; sadisme, masochisme, nekrofilie en profanasie kom voor in die gebeureverloop. En dit is juis 'n hiper-verestetiseerde lewensvisie, 'n fanatieke skoonheidsoeke te midde van die vrees vir en afsku van 'n sterflifke en oënskynlike sterwende natuur, wat lei tot die dekadente kultus met sy voorkeur vir die artifisiële, die ontvlugting in die okkulte en die eksotiese, en die waarneming van skoonheid ook in pyn, in wreedheid, en in die boosheid self.

Die dekadentisme is 'n tendens wat merkbaar word vanaf die middel van die $19 \mathrm{e}$ eeu en reeds rigting kry met die l'art pour l'art-beweging wat al verwoord is in Gautier se inleiding tot sy roman Mademoiselle de Maupin (1835). Die literêre dekadentisme bereik 'n klimaks in Joris-Karl Huysmans se $A$ Rebours (1884) en Là Bas (1891). In Engeland was dit eers die digter Swinburne, maar later George Moore (Confessions of a Young Man, 1888) en dan boweal Oscar Wilde deur die roman The Picture of Dorian Gray (1891) wat sinoniem met die dekadentisme was. Die essensie van die (Engelse) fin de siècle is visueel voorgestel deur Aubrey Beardsley se tekeninge, en veral sy illustrasies by Wilde se 'bybeldrama', Salome (1894). Die kenmerkende anti-burgerlike, hedonistiese en obsessief-estetisistiese gees word in Italiaans die duidelikste vorm gegee in D'Annunzio se roman ll Piacere (The Child of Pleasure, 1896). In Duitsland is Stefan George met Algabal (1892), waarin die eksotiese, tipies dekadente Heliogobalus-motief ontgin word, die verpersoonliking van die literêre fin de siècle. (Kyk Fletcher, 1979; Gilman, 1979; Goedegebuure, 1983, 1987; Grobbelaar, 1991; Van Buuren, 1982, 1984; Vandevoorde, 1989.)

\subsection{Volkskuns en nasionale letterkunde}

Wanneer 'n mens die terme volkskuns en nasionale letterkunde opneem, ontstaan daar 'n byna vanselfsprekende assosiasie met die Vlaamse en Afrikaanse (Taal-) Bewegings en die vroeë letterkundige bedrywighede wat daaruit gespruit het. En dan is dit 'n betekenisverband nie soseer in die sin van kuns deur die volk nie, dit wil sè dié van folklore, volkslegendes of volksrympies en -liedjies nie. Dit is eerder die deur latere generasies byna aksiomatiese aanname dat in albei bewegings, dit die opheffing van 'n mindergeagte volksof taalgroep, die daarstelling, bevordering en bevestiging van 'n geïdealiseerde volkskultuur en daarom ook die uitsluiting van sogenaamde volksvreemde en volksvyandige elemente is wat die basis vir alle bedrywighede vorm. Eintlik dus kuns ter wille van die volk, met laasgenoemde ' $n$ abstrakte idee wat in albei gevalle gereduseer is tot 'n spesifieke taalgroep wat verenig is deur sy opposisie teen daardie ekonomiese en politieke omstandighede wat die voorspoed of selfs voortbestaan van die groep bedreig het.

Dat in die Vlaamse beweging, veral gedurende die periode tot 1914, die kultuur (en dus ook die letterkunde) sistematies as 'n funksionele instrument binne die proses van nasiebou gebruik is, word onomwonde in tydgenootlike manifeste, literêre kritiek en skeppende werke verklaar. 'n Analise van uitsprake gemaak nog tot die 1890 's deur die bekendste letterkundige kritici wat in baie gevalle ook die kultuurleiers en die skrywers was, toon hulle sisteembevestigende propagering van 'n milde realisme en 'n volkse romantiek. 
Byvoorbeeld, die oorheersende kunsstroming, die Naturalisme, word as 'n Franse aberrasie verwerp (Debbaut, 1989:28); die Simbolisme is afgeskryf as 'n "ziekelijk toestand", uiteraard Frans en Waals, en daarom "verderfelijk voor onzen volksgeest, voor al wat wij liefhebben, voor al wat bij den vreemde onze glorie uitmaakt" (Janssens in Het Belfort (1893), gedokumenteer in Vervliet, 1982:232). Die groot Max Rooses se uitspraak van 1868 dat "het (literêre) werk moet passend zijn voor het publiek waarvoor het gemaakt is" (aangehaal deur Somers in Deprez \& Gobbers, 1990:232-247) klink nie net soos 'n prelude vir die geluide gemaak by die Welkomse leeskringseminaar in 1991 nie, maar bly inderdaad lewenslank sy kritiese riglyn: naamlik dat 'n literêre teks eers werklik sinvol is wanneer dit 'n volksnasionale gebondenheid verwoord (Vlasselaers, 1985:163). In 1927 nog sou Rutten met groot stelligheid verklaar: "(D)e Vlaamse letterkunde is 'n volkskunst ... die met fierheid of 'n zekere wellust haar sympathie voor't volkseigen uit" (Rutten, 1928:16, 17). Sowel Vervliet (1982) se tweedelige studie oor die aard en inhoud van Vlaamse literêre tydskrifte wat gedurende die fin de siècle gepubliseer is, as Vlasselaers (1985) se voortreflike analise en evaluasie van die ontwikkelende Vlaamse literêre bewussyn tussen 1840-1893, dokumenteer noukeurig hierdie dominante kode van 'n 'volkse letterkunde', wat sowel tematiek, artistieke tegnieke en verspreidingsvorme en -middele betrek.

Dit is eers vanaf 1880 met Pol de Mont se bekendstellings van die internasionale modernisme, en later deur die jonger skrywersgenerasie rondom die tydskrif Van Nu en Straks (18931901), dat 'n periode van vernuwing begin en pleidooie vir 'n meer outonome en estetiesformalistiese kuns opklink. Hoewel hierdie nuwe strewe in Vlaandere nooit die ekstreme vorms van die kosmopolitiese en elitaire individualisme - soos veral gemanifesteer in die Simbolisme en die dekadentisme - aangeneem het nie, is die woordvoerders van die vernuwing meestal as gevaarlike radikales en verraaiers van die Vlaamse saak beskou. Dié soort oordeel is eksplisiet uitgespreek in die kolomme van kerklike en politieke blaaie asook in die selfregverdigende jurieverslae vir letterkundige pryse (Vlasselaers, 1985:125). Dit is opvallend dat in die tydgenootlike en gekanoniseerde skeppende prosa, ' $n$ aansluiting by die modernisme nouliks sigbaar was. En selfs die leidende figure onder die 'nuwe' geslag, soos onder andere August Vermeylen en Prosper van Langendonck, het die kunstenaar se betrokkenheid by 'n volk en 'n nasionale roeping, steeds in die literêre teks gesoek (Debbaut, 1989:55; Vlasselaers, 1985:189).

\subsection{Nasionale literatuurbeskouing in die Afrikaanse letterkunde}

Dit is byna oorbodig om die analoë situasie in die vroeë Afrikaanse letterkunde, dit wil sê die prosa van \pm 1910 tot 1940 , breedvoerig uiteen te sit. In destydse literatuurbeskouings word daar byvoorbeeld verwys na die "opbloeiende prosakuns wat wortel in 'n eie, nasionale romantiek" (Dekker in 1935, soos aangehaal in Grobbelaar, 1991:119, my kursivering), en word die kuns wat "oprys uit die ontroerde dieptes van 'n ernstige mens ... wat diep gewortel is in sy volk en in die bodem van sy volksaard", as ideaal voorgestel (Malherbe in 1941, soos aangehaal in Grobbelaar, 1991:120). In hoe 'n mate die vroeë Afrikaanse prosatekste uiteraard as tipiese volkskuns beskryf, en hoe sodanige volkskuns inderdaad as die kanon van daardie vroeë periode aanvaar is, word duidelik selfs wanneer 'n mens net die kategoriserende hoofstuktitels in ons literatuurgeskiedenisse tot vandag toe nog, bekyk (Roos, 1990:14). Die uitgesproke propagandistiese en didakties-moraliserende grondslag van die G.R.A. en van die hele Eerste en vroeë Tweede Afrikaanse taalbewegings, die ideologiese nalatenskap van die Boereoorloë en die Rebellie wat onder meer tot 'n toenemende sosiopolitieke en kulturele volksbewussyn onder Afrikaanssprekendes gelei 
het, was alles faktore wat gedurende 'n era van hewige roeringe die karakteristieke klimaat vir 'n byna geheiligde, volksgerigte letterkunde sou skep.

\section{Dekadente spore in die 'kuns van die volk'}

\subsection{Die Vlaamse en Afrikaanse manifestasie van dekadentisme en fin de siècle}

Die kernvraag is nou óf en hóé die dekadentisme, en veral die subversiewe aard van die fin de slècle-tendens, enigsins by die algemene beeld van Vlaamse en Afrikaanse volkskuns die beeld wat tot nog toe deur alle kanoniserende literatuurgeskiedskrywings onderskryf is - inpas. Per slot van rekening, nie net die situasie soos hierbo uiteengesit nie, maar ook die ou Vlaamse gallofobie, en die verwydering in tyd en ruimte tussen die vroeë Afrikaanse prosa en die Europese fin de siècle, maak 'n spontane en grootskaalse uiting van die dekandentisme in albei letterkundes hoogs onwaarskynlik.

'n Mens kan ook in gedagte hou dat selfs wat die meer vrysinnige en serebrale Nederlandse prosa betref, Anbeek die hele dekadentisme met een enkele sin afmaak. Sy uitspraak oor Couperus se De berg van licht (1905) is, dat "met enig recht kan men de laatstgenoemde roman tot het decadentisme rekenen, een stroming die in Nederland verder weinig voet aan de grond gekregen heeft" (Anbeek, 1990:100). In Goedegebuure se Decadentie en literatuur (1987) handel een kort hoofstuk oor dié verskynsel in Nederland, en beskryf hy dekadentisme as op die uiterste kantlyn van die Nederlandse fin de siècle. Hy noem ook Couperus, hoofsaaklik weens die oorkoepelende ondergangsmotief wat deur die hele oeuvre loop, en betrek dan Jacob Israëls de Haan, en baie sydelings vir Van Deyssel en Arij Prins. Anbeek en Goedegebuure se werk was reeds gepubliseer toe nuwe navorsing aan die lig bring dat die Nederlandse skrywers van die eeuwending wel deeglik kennis gedra het van die dekadentisme. Mev. Couperus het Wilde se The Picture of Dorian Gray in Nederlands vertaal, en voordat Salome in Engeland beskikbaar was, het dit reeds in Nederland verskyn. Van Eeden onder andere, het in sy opdraggedigte vir Kloos se sestigste verjaarsdag die gehuldigde vergelyk met Verlaine en Oscar Wilde, terwyl Arij Prins byvoorbeeld ' $n$ intense en langdurige korrespondensie met Huysmans gevoer het. (Vergeer, 1990:188-189). Goedegebuure sien egter die gehele Nederlandse manifestasie van die dekadentisme as ' $n$ "individuele bevlieging van voorbijgaande aard" (1987:71).

Die navorsing waarvan hierdie artikel verslag doen, relativeer en herevalueer dus die tans bestaande geringskatting van die fin de siècle-tendens.

\subsection{Die Vlaamse fin de siècle - Vlasselaers se rekonstruksie}

Dit is weer Vlasselaers wat 'n verhelderende rekonstruksie van 'n bestaande dekadente bewussyn tydens die Vlaamse fin de siècle maak. Dekadent is eers veralgemenend in die 1880 's as skelwoord in die stryd teen die vernuwers gebruik, en selfs die uitgesproke jong moderniste het hulle van die Franse 'dekadensieliteratuur' gedistansieer. Vir die jong Vlaminge was die apokaliptiese sfeer van die Europese fin de siècle onvanpas binne hulle eie strewe na regenerasie. Eers in die middel-negentigs kom kritici soos Vermeylen en Emmanuel de Bom met verwysings na 'n 'siek' wêreld, 'n skeptiese lewensvisie en na oorspanne, letargiese verhaalkarakters wanneer hulle die nuwe literêre beskouings bespreek. Hulle positiewe uitsprake oor maatskaplike betrokkenheid en gemeenskapsin, 
"het belangstellen in de kleinen, het alzegenend medelijden", beteken egter dat selfs dié twee 'radikales' nooit die deelwees van die volk te midde van 'n bewuswees van die fin de siècle kon aflê nie (Vlasselaers, 1985:192-195).

\subsection{Manifestasie van 'n outentieke dekadentisme}

Dit is deur die herlees van enkele primêre tekste self, en ook deur in retrospeksie kritiek van tydgenote en latere leesgenerasies op daardie besondere tekste te hersien, dat die duidelikste leidrade na die eksplisiete manifestasies van 'n outentieke dekadentisme voorkom.

\subsubsection{Het ivoren aapje}

Herman Teirlinck se Het ivoren aapje (1909) is die werk wat 'n mens dalk die eerste en die maklikste kan identifiseer. Dié roman geskryf deur 'n dertigjarige Teirlinck, word in 'n tersyde deur Van Vlierden genoem as 'n soort literêre versamelpunt van die kosmopolitiese dandyisme, 'n term wat Van Vlierden herhaaldelik en steeds neerhalend gebruik as noemer vir die dillettantisme en "artiestensfeer" van 'n Brusselse skrywersgroep geskaar om die tydskrif De Boomgaard (1909-1911). Hierdie gekunstelde dandyisme stel hy teenoor die prosawerk van Timmermans ("impressionistiese heimatkuns") en Van de Woestijne (esoteriese mistiek) se werk, en bemerk wel 'n oppervlakkige ooreenkoms met die Teirlinckroman (Van Vlierden, 1969:59-77). Dit is dié soort gekanoniseerde veralgemenings en evaluasies wat as prikkel gedien het om die drie outeurs en hulle vertellings vir die doel van hierdie artikel weer te beskou.

Vanuit 'n agternaperspektief lees Het ivoren aapje inderdaad soos 'n Vlaamse brevier der décadence, hoewel dit binne die Teirlinck-oeuvre klaarblyklik 'n eenmalige eksperiment, indien dan nie ' $n$ 'individuele bevlieging' nie, was. Dié "roman van Brussels leven" verhaal die luukse dog ledige bestaan van die "nerveuze" Francine, die diaboliese Rupert Sörge, die dandy Verlat, en beskryf bordele, bohemers en skatryk bourgeoisie in 'n sfeer van opulente interieurs, skitterende juwele en kostuums en bedwelmende parfuum. Van Vlierden se oordeel dat Teirlinck 'n kosmopolitiese mode bloot tematies naskryf, is myns insiens egter 'n miskenning van of onkunde omtrent die outeur se merkwaardige stilistiese aansluiting by die suiwer dekadentisme. Die beeldryke, gekunstelde taal, daardie uitbuiting van "die pronkende en pralende woord" (Goedegebuure, 1987:91) word absoluut ontgin in die uitvoerige beskrywings van verestetiseerde scènes en estetiese objekte. Daar is byvoorbeeld die kumulerende leliemotief, die opvallende gebruik van die kleure groen en pers (Francine se oë, die blomme, die vrugte, die klere en juwele, die meubels en versierings), asook die daarstelling van die homme fatale met sy bleek gelaatskleur, "lokkend blauwzwarte haar" en gloeiende oë. Sinnelike genot en wellus word afwisselend gekontrasteer met 'n "lui en lauw" houding; emosies en lewende dinge word verwoord in terme van die artifisiële en die verrottende; vergelyk net dié afskeidstoneel tussen die weke Verlat en Milly, sy femme fatale:

Tot op de rand van de tafel trok ze de lauwe lclickelken (wat vasgemaak was met "purperen klokjes" H.M.R.!) uit, vingerde wellustig in dat harde rood, wondde met haar onrustige nagels de weerloze petalen. Hij voelde de ongeschikte nacht, de mizeric van de scherpe tabakslucht, de nasmaak van't overspelig fecstgepraat, gemengd met de zuurheid van bedorven wijnmoer en bedervende vruehten. (Teirlinck, 1983 (1909):262.) 
Dat Teirlinck self sy werk in 'n "Voorbericht" (bl. 9) moes verdedig by die lesers wat die verhaal as 'n "spiegel van de werkelijkheid", 'n sleutelroman dus, wou interpreteer, en dat hy die roman suiwer as 'n vrug van die verbeelding - hoewel psigologies juis - beskryf, toon myns insiens dat nóg skrywer nóg tydgenootlike lesers die dekadentistiese stemming en styl as die primêre verhaalkode kon of wou erken. Vir Lissens is Teirlinck die enkele waardevolle kern van 'n andersins niksbeduidende groep wat die etikette van "estheticisme, dillettantisme, decadentie en amoralisme" verdien, 'n groepie outeurs wat "een apart gebied in de Vlaamse letterkunde" vorm en van wie slegs die name eenmalig in sy literatuurgeskiedenis verskyn. Lissens verwys wel baie vaagweg na 'n "onduidelike" lyn wat getrek kan word vanaf Pol de Mont, deur die "sensualistische verbeeldingsproza" van Van de Woestijne en die "goudsmidsproza" van Toussaint van Boelaere, tot by Teirlinck. Die gekanoniseerde oordeel was egter dat Teirlinck se "cerebraal estheticisme hem belet het tijdeigen ideaal van de gemeenschapskunst te verwezenlijken", sodat sy oeuvre "een produkt van glascultuur" bly (Lissens, 1967:122-125).

\subsubsection{Van de Woestijne: gekunstelde dekadensie}

Hierdie negatiewe evaluasie van 'n outeur omdat hy "zich niet engageert", word egter heeltemal gewysig wanneer Lissens vergelykenderwys Van de Woestijne beskou. Die veelseggende frase, 'n "overrijpe en decadente zintuiglijkheid", word wel byna ongemerk gebruik, maar die intens-persoonlike en biegtende, die "onvervalst Vlaamse toon" waarin ook nog 'n "vage godsdienstigheid" deurskemer, laat Lissens besluit dat Van de Woestijne se oeuvre "een van de grootse uitingen is van de herfstige kunst om de eeuwisseling" (Lissens, 1967:114). Dit is ook die een outeur wat volgens Van Vlierden wél die magteloosheid van die fin de siècle kon besweer (1969:180), en wat deur tydgenote en medeskrywers eers as "onbruikbaar en ontzenuwend" geoordeel is, om later deur dieselfdes geloof te word as een in wie "vloeiden plots samen al de fijne gevoeligheden eener ten uiterste geprikkelde en sensueel-zatte periode. In hem werd belichaamd de fin de sièclemensch" maar een in wie "het morbide ... langzaam geweken is voor het religieuze" (Gijsen, s.j. -1940:65-67).

Wat sê die Van de Woestijne-tekste self vir my as hedendaagse leser? Die voorwoorde by twee bundels met verhale waarvan sommige reeds al in 1894 geskryf is, lees vandag besonder insiggewend. In Janus met het dubbele voorhoofd (1908), opgedra aan De Bom, word die waarskynlik nougesette en reggeskape leser in 'n "klein sermoen" gewaarsku teen die boek se "onbetamelijke grapjes", die "gebroken perspectieven", "de liegende maskers van bitterheid" en "wat rottende blaêren" (Van de Woestijne, 1917). In Afwijkingen (1910), opgedra aan Vermeylen, word die leser van "deze laat-komende eeuw" met 'n "binnenleiding" bekend gestel aan 'n boek wat 'n "proef-veld vol onverduwbare en weinigvoedzame keien, en waarlijk al te gevoelige slakken" is (Van de Woestijne, 1910). Albei bundels word gekarakteriseer deur'n kumulasie van herhalende en gelyksoortige woorde, beelde, karakters en motiewe weergegee in 'n unieke sierstyl. Die gebeurelyn word gerig deur dood en angsaanjaende droombeelde en die okkulte; die gekunstelde Antieke en eksotiese tye en ruimtes vorm die milieu in verhale soos "De vrouw van Kandaulus" en "De zwijnen van Kirke"; die oorkoepelende duisternis en die sombere sfeer word afgewissel met kleure soos groen en pers en wit. Die verhaalwêrelde bestaan uit oordadig-luuksueuse interieurs, vol bedrieglike spieëls en wanstaltige, groteske figure wat aanwesig is op tonele van koorsige wellus of verlammende lusteloosheid. Telkens is die hooffiguur ' $n$ femme fatale, bedek met kosbare juwele en die oorsaak van verraad, individuele vernietiging en 
algemene verval.

Een van die verhale in Afwijkingen, 'n teks reeds in 1895 deur die toe sewentienjarige Van de Woestijne geskryf, kan ons vlugtig as verteenwoordigend van hierdie prosas bekyk. "Dood van Salomo" (Van de Woestijne, 1910:39-48) behoort 'n mens eintlik hardop te lees. Die byna oorweldigende klankrym van die inleidingsinne is deel van die hoogs evokatiewe, "gedreven, geciseleerde 'style artiste'" (Rutten, 1959:215) wat nie net tipies van die gekunstelde dekadentisme is nie, maar ook die hele eksotiese, oosterse en 'oorryp' verhaalsfeer uitmuntend verbaliseer. Dit is betekenisvol dat Van de Woestijne veertien jaar later in 'n tweede versie hierdie "barokke overladenheid" nog mér welig en welluidend 'verbeter' het (Rutten, 1959:214). Die kleure "paars"/purper (by beskrywings van die sonstrale, terrasse, hare, mantels, ens.), swart (die horison, die skarabeë as versierings) en groen (symateriaal, die lug) word gebruik om 'n skemertoneel ("stervende zon", "doode licht") in 'n weelderige paleis uit te beeld. Daar is oordadige prag en praal, maar tog is die toneel "traaglijk en troosteloos", en die paleis omring deur 'n barre woestyn. Die gekunstelde skoonheid van bouwerk en dekor ("albast van een tuinplaats", "zuilen van onyx", "bronzende dienaar-schoften") staan paradoksaal teenoor die bewoners met hulle "bleeke leden", die "onroerende krijgers", 'n "trage koning, moe". Die oorsaak van hierdie degenerasie waartydens die hele stad "verschromplen in donkrende walmen", is die koningin van Skeba, uitgebeeld as 'n tipiese femme fatale. Salomo onthou haar as beeldskoon, 'n "te witte lelie", gekleed in groen sy, haar vingers en enkels behang met seldsame juwele; sy wat "zijn nek had gebogen lijk bliksemen knakken den top van een ceder" (bl. 45). Sonder haar kan hy nie bestaan nie, en met die klaende musiek van basuine en tromme, terwyl 'n rilling tot in sy tande oprys en hy die "allerlaatste purper der zon" aanskou, gaan Salomo sugtend die einde van sy ryk tegemoet.

Hierdie verhaal met sy alles-deursyferende ondergangstoon, die verestetisering van die verval, die suggestie van sadomasochisme en die primaat van artifisialiteit en eksotisme, plaas die jeugdige Van de Woestijne binne die sentrum van 'n onmiskenbare en outentieke literêre dekadentisme. Rutten bespreek en analiseer in sy omvangryke en waardevolle studie oor Van de Woestijne se prosawerk onder andere "Dood van Salomo" op indringende wyse, maar terwyl hy tereg die "atmosferisch-impressionistisch" styl en die outeur se emosionele aansluiting by die Simbolisme beklemtoon (Rutten, 1959:52-63, 112 en verder), oordeel hy in terloopse opmerkings dat Van de Woestijne slegs 'n jeugdige, wankelrige navolger van die fin de siècle "op zijn smalst" was. Eers was hy dus "ontworteld" en "aangetast", maar in sy later werk sou hy die "ziekte" ontgroei op weg na die veelgeprese asketies-mistieke vergeesteliking (Rutten, 1959:191-192). Myns insiens is hierdie uitsprake 'n totale onderskatting en verkeerde interpretasie van 'n besonder boeiende versameling verhale, veral in die lig van my strukturele analise soos hierbo gerapporteer.

\subsubsection{Felix Timmermans: dekadentistiese 'doodsverhale'}

Wanneer 'n mens in ag neem hoe die konvensionele kritici Van de Woestijne se "afwijkingen" en "dubbele voorhoofd" sou doodpraat of as onbelangrike jeugwerk vergoeilik, klink dit aanvanklik werklik vergesog dat ek Timmermans, daardie woordbouer van 'n Vlaamse utopia, deur 'n dekadente bril wil beskou. Felix Timmermans is tog sinoniem met Pallieter, met Het kindeken Jezus in Vlaanderen en met Boerenpsalm. Hy was die "briljante vertegenwoordiger van de volkskunst" (Westerlinck aangehaal in De Ceulaer, 1959:5), sy prosa so "spontaan en volks" (De Ceulaer, 1959:9), 'n "volkskind", "folklorist in zijn hart", 
"geworteld en gegroeid uit't onbezoedeld Vlaams wezen" (Rutten, 1928:18, 20, 36). Die Heimatskunst waarmee hy vereenselwig word, is dekades lank veral in Duitsland met die grootste entoesiasme gelees. Daarom dalk dat die één bundel wat in sy eie opdrag nooit in Duits vertaal is nie, die huidige leser wel sal interesseer. Schemeringen van de dood (1910) dui deur sy titel al op 'n spesifieke en hier relevante motief. Die bundel word deur die enkele kritici wat dit wel vermeld, 'n produk van "geestelijke puberteitsjaren, lugubere verhalen van geringe literaire waarde", komende uit 'n periode van "geestelijke ontreddering" genoem (De Ceulaer, 1959:12, 23). Rutten lees die bundel heeltemal vanuit ' $n$ psigologistiese perspektief: elke verhaal voer hy terug na die invloed van 'n bepaalde vriendekring, 'n spesifieke situasie, 'n individuele reaksie op skilderye, musiek, selfs op die lees van Het ivoren aapje. Die verhale skyn dus "echte spiegels van ... een geestelijke verziekelijking", verhale met 'n soort "jongensachtig gedurfde aandikken", 'n "romantiese opzettelijkheid", "de taal te weelderig". Benewens 'n enkelverhaal van Jef Mennekens, word hierdie vertellings ook as "alleen in hun soort in de Vlaamse literatuur" beskou (Rutten, 1928:66,73-74). Dit is eers vyftig jaar na die eerste verskyning dat Hubert Lampo die vertellings as "schromelijk beneden hun waarde geschat" oordeel, hoewel hy ongelukkig volstaan om die "gewaagde inhoud" in slegs 'n halwe bladsy en vanuit 'n psigoanalitiese perspektief saam te vat (Lampo, 1961:9-10).

Timmermans het waarskynlik self sy kritici en lesers op hierdie psigologistiese en geringskattende dwaalspoor gehou. In die werkie Uit mijn rommelkas waarin hy oor die ontstaan van Pallieter en Het kindeken Jezus in Vlaanderen skryf, roep hy asof in 'n apologetiese bieg die beeld van homself as 'n afgedwaalde jongeling op, verblind deur die kosmopolitiese en elitair-intellektuele, mistieke sfeer van sy kunstenaarsvriende. Sy verhale is geskryf toe sy lewe "omsluierd was met een droeve en angst-makende allerzielennevel"; hyself iemand wat "in die schemer en stervende atmosfeer gekomen was door het occultisme" (Timmermans, s.j(1951):20). Dis opvallend dat daar by geen van die bogenoemde uitsprake 'n vermelding van die fin de siècle of die dekadentisme is nie, terwyl die verwysings na Maeterlinck, Poe, Huysmans en Teirlinck wel deurgaans voorkom. En oor die geldigheid van 'n outobiografiese basis in hierdie bundel 'doodsverhale' hoef die huidige leser nie te argumenteer nie, maar dat die karakteristieke sfeer van die dekadentisme onmiskenbaar in Schemeringen van de dood bestaan, toon die teks self.

Dit is weer eens die kleure groen en swart en pers waardeur die alles-deurdringende toon van somberheid, degenerasie en dood byna visueel ontstaan. Al die verhale speel in 'n herfstige of winterswêreld af, binne 'n grootstadsmilieu, of in 'n totaal verlate en van alle lewe en skoonheid ontdane ruimte. Kille en donker binnekamers is meestal die speeltoneel waarop die homme fatale en fatale vrou toetree, omring deur Wagner-musiek, geobsedeer met die okkulte; 'n lelie die enigste 'natuurlike' voorwerp in die afgesonderde ivoortoringbestaan. Dat Timmermans so ' $n$ tipiese dekadente teks in die vorm van ' $n$ tradisionele grieselverhaal opbou, is die soort 'verhullende' tegniek wat dikwels deur Afrikaanse outeurs soos Leipoldt en Marais ook gebruik is. Maar ook by Timmermans is die vertellings nie blote 'spookstories' nie; die bekende motiewe, die kenmerkende styl en die algemene tematiek sluit te direk by die dekadentisme aan. Die uitbeelding van ' $n$ selfgenoegsame, introverte man wat konvensionele seksuele verhoudings verwerp, die vrou as bleek en senusieke figuur wat deur haar luste die man se fisiese en geestelike ondergang veroorsaak, kom in die meeste verhale voor. Hierdie toneel uit "De kelder" spreek vanself:

In de ruime, goud-belederde zaal stond niets dan een lange, groengetapijte tafel, ecnige zware ciken stoclen en cen groote donkere kast waarin mijn hocken met zorg gerangschikt stonden. Daar mijn 
boeken lezend te zitten, was mijn leven ... . Mina zat voor het venster en keek in de donkere eenzame straat die vreemd betint was ... . Zij draaide het hoofd cn stortte haren blik in den mijne. En weer zag ik die ogen, zoals ik ze eens zag in den schouwburg, toen het Fatum in het orkest losbrak. Weer zag ik ze rijzen en eindelik groot worden als werelden, maar nu kwam er een licht uit als uit de oogen eener kat ... . Incens kletste de waarheid als een steen op mijn hoofd. Mijn vrouw was zinnelijk. (Timmermans, 1910:55-56.)

\subsection{Parallelle tussen Afrikaanse en Vlaamse tekste}

$\mathrm{Na}$ my analise van enkeltekste uit die Vlaamse letterkunde, word die manifestasie van die dekadentisme in die vroeë Afrikaanse prosa hier net baie kursories beskryf. Dié buitengewone en boeiende onderwerp is op indringende en uitgebreide wyse geboekstaaf in 'n proefskrif vir die D.Litt et Phil-graad wat onder die outeur van hierdie artikel se leiding voltooi is (Grobbelaar, 1991). Uittreksels en verwerkings van dié proefskrif sal onder ons albei se name gepubliseer word, en daarom word vrylik van daardie navorsing en bevindings gebruik gemaak om die opvallende parallelle tussen die Afrikaanse en Vlaamse tekste uit te wys. Die situasie binne die Afrikaanse prosa word ook hoofsaaklik as vergelykingsbasis beskryf. In een van die hoofstukke van die ondersoekverslag identifiseer Grobbelaar outeurs soos Reenen J. van Reenen, H.A. Fagan, I.D. du Plessis en dan in die besonder Eugene Marais en C. Louis Leipoldt as sou hulle 'n onderbroke maar duidelike lyn binne 'n onmiskenbare dekadente stroming in die vroeë Afrikaanse prosa vorm.

\subsection{1 'n Dekadentistiese tendens in Marais se oeuvre}

In Marais se oeuvre is dit veral die fiksionalisering, die dramatisering en die opmerklike verestetisering van 'n skynbaar gewone en verifieerbare werklikheid wat in Marais se oeuvre die dekadentistiese tendens onderlê. Die uitbeelding van die natuur en van lewende objekte in terme van die artifisiële, kom uiters gestileerd voor in verhale soos "Salas Y Gomez", "Swart bobbejane of amnestie", "Die ondergang van die tweede wêreld", ensovoorts; verhale wat hy in die vroeë twintigerjare begin skryf het en wat oor 'n lang tydperk in verskillende publikasies verskyn het. Die femme fatale en die dandy tree by herhaling op: in "Modjadje", "Die pas van Santary" en "Die man met die mantel".

Terwyl Marais anders as die Europese dekadentis nie die boheemse grootstadslewe uitbeeld nie, is dit werklik insiggewend hoe hy die Natuur as 'n bose en gekunstelde, maar skone, mag beskryf. Vergelyk byvoorbeeld: "Dit was 'n sonderlinge blou lig met sommige van die skakerings van perlemoer op die horison ... . Dit was asof ons onder 'n omgekeerde koppie van deurskynende blou porselein was, versierd met miljoene goudspikkels" (so lyk die maanlig in "Swart bobbejane of amnestie") en:

Dag en nag het die skatte van die Meisie op die Aarde uitgestort, totdat hy dit nie meer kon uithou nic ... . Die diamante en die pêrels het sy vleis verskcur en stukke daarvan het in 'n bloedige stroom van sy hoof en opgehewe hande oor sy gesig en liggaam afgeloop. ('n Beskrywing van 'n storm uit die ongebundelde verhaal "Die storm", 1925.)

Die verestetisering van pyn en dood, en die bewussyn van 'n apokaliptiese sfeer, is oorbekende motiewe binne die Marais-oeuvre. 


\title{
3.4.2 Leipoldt: naklanke van die fin de siècle en dekadentisme
}

Dit is egter boweal C. Louis Leipoldt, daardie digter van volksgedigte soos "Oom Gert vertel", lid van die volksgevierde driemanskap, en algemeen bekend as maker van die 'eenvoudige' slampamperliedjies wat deur Grobbelaar as onteenseglike en direkte voortsetter van die dekadentisme beskryf word. Leipoldt self het in 'n voorwoord tot sy verhaalbundel Waar spoke speel (1927) 'n bewustelike verband met die werk van Huysmans en Oscar Wilde gelê; hy spreek hom ook in positiewe terme uit oor wat hy noem "degenerasie as 'n aspek van oorverfyning". 'n Byna aggressiewe teensin in die bourgeoisie, 'n totale a-Christelike lewensvisie, 'n narcistiese en blykbaar ook outo-erotiese leefwyse word eksplisiet in sy uitgebreide prosa-oeuvre gereflekteer. Seksuele perversiteite, androginie en sadomasochisme is belangrike motiewe in verhale soos "Die dwergvroutjie" (1937) en "Die donker huis" (1931), terwyl die homme fatale, die femme fatale en hulle assosiasie met die okkulte by herhaling voorkom. Die tipies-dekadente weergawe van die lewende en natuurlike in die vorm van artifisiële oordaad, sal seker vir dié leser wat Leipoldt net as digter van die sentimentele "Oktobermaand" ken, vreemd in die volgende uittreksel lyk:

\begin{abstract}
In die bolug het dic ligte blougroen soos 'n laag van helder beril nog gelewe, en daardeur en daaroor het rillinge van krisopraasgeel en amarantpurper gegaan, wat met die donkerder hellinge van die bergrande versmelt het. Dic berge self was nog wonderliker geklee in kleure wat elke oomblik verander het, net soos die oppervlakte van 'n alcksandriet sy tinte verwissel. Topaas was dit eers en dan donker robyn, met die glinster van galsedoonsteen daartussen, en die blink punte van liggekroonde rotsspitse daarbo; dan weer, die donkergroen van toermalyn, versterk, in die diep klowe, deur swaarder skaduwees tot 'n swart-blou van asuriet of die blou van die diep, diep see as daar 'n donderwolk oor swewe" (Uit "Dic Koranna se kopbeen" 1927.)
\end{abstract}

Die eksotiese milieu wat in sovele van Leipoldt se vertellings tot stand kom, die herhaaldelike uitbeelding van wanstaltiges, die demoniese maar ook die $d a n d y$, die byna obsessiewe verwysings na juwele, na die kleur groen en die dikwels enumererende, hoogsgestileerde vertelstyl - dit alles lei die hedendaagse leser tot die besef dat hier 'n late maar duidelike naklank van die fin de siècle en die dekadentisme was.

\section{Slotsom}

Die voorgaande verslag, gebaseer op 'n kritiese beskouing van bestaande sekondêre bronne en 'n analitiese herlees van verskillende prosatekste, lei tot die volgende slotsom. Dit wil voorkom of die dekadentisme en die tipiese fin de siècle-gees nooit 'n duidelike literêre stroming op die voorgrond van of die Vlaamse of die Afrikaanse prosatoneel was nie. Van 'n identifiseerbare tendens kan 'n mens egter beslis praat.

\subsection{Vlaamse dekadensie: 'n beperkte tydsduur}

Dit blyk nou dat die tendens in Vlaandere van beperkte tydsduur was en ook nie deur die hele prosaoeuvre van die relevante outeurs voorgekom het nie, maar eerder in enkele of enkelwerke. Ek meen ook dit was aanwesig by outeurs wat klaarblyklik deur die kanoniserende kritiek as prosaiste nie so hoog geskat is nie (De Bom, Van de Woestijne), of wie se prosa wel hooggeag was, maar dan ten opsigte van hulle latere werk en binne ander kategorieë (Timmermans, Teirlinck), of by die wat deur die literatuurgeskiedskrywers as in ieder geval van weinig waarde beskou is (Toussaint van Boelaere, Jan van Nijlen, Andre de 
Ridder, Paul Kenis, Jef Mennekens. Vgl. De Vree, 1933). Dit is dalk in die geval van die Vlaamse skrywers makliker om die dekadentistiese teks as blote jeugwerk of 'n modegier te beoordeel, nie net omdat hulle in tyd en ruimte nog so na aan die fin de siècle was nie, maar ook omdat die genoemde werke eerder 'n algemene Europese kultuur (die stadsmilieu, die verwysings na die Antieke) as 'n spesifiek Vlaamse wêreld verbeeld. Maar blykbaar was selfs hierdie enkele tekste as 'n subversiewe aanslag op die tradisionele en geïdealiseerde letterkunde beskou, veral in die lig van die tydgenootlike kritiek (maar ook nog heelwat latere kritici) se geringskatting en selfs verswyging daarvan. Dis ook vir my betekenisvol dat van die bekendste outeurs later dikwels apologeties en selfs afwysend teenoor hulle eie werk staan om só hulle formele vereenselwiging met die establishment-kultuur te betuig. Dat die etiket/term dekadent byna angsvallig vermy is, kan ek nie net aan tydgenootlike onkunde omtrent die stylvorm toeskryf nie. 'n Uitgesproke identifikasie met 'n volksvreemde verskynsel sou nie by 'n gevierde volkskunstenaar pas nie, en moes myns insiens daarom deur (die later gevestigde) outeur en die gevestigde literêre wêreld verswyg word.

\subsection{Die Afrikaanse dekadente literatuur}

Vir die Afrikaanse dekadente literatuur lê die aksent volgens my ietwat anders. Hoewel die genoemde outeurs ook in die meeste gevalle bekend was as volksdigters, of as dramaturge, en hulle prosa-oeuvre ook heeltemal deur die tydgenootlike en baie latere kritici geringgeskat is, was daar weinig sprake van 'n apologetiese of afwysende houding teenoor die eie werk. Daarbenewens was Marais en Leipoldt by uitstek outsiders, in mindere of meerdere mate afsydig teenoor die heersende sosiale, seksuele, morele, religieuse, etiese en selfs party-politieke konvensies. Dat hulle sowat dertig jaar ná, en in 'n wêrelddeel ververwyderd van die hoogtepunt van die Europese fin de siècle geskryf het, verklaar myns insiens die opmerklike inheemse manifestasie van die dekadente stemming in die Afrikaanse teks. (Vgl. ook Roos, 1990:32.) Hier is dit nie die grootstad of die somber Europese klimaat of die boheemse kunssfeer wat uitgebeeld word nie, maar 'n outentieke Afrika-milieu met die natuur as 'n grootse, dikwels vyandige mag.

\subsection{Die herlees en saamlees van Vlaamse en Afrikaanse tekste}

Dit is egter baie interessant dat in sowel die Vlaamse as die Afrikaanse prosa die karakteristieke styl, stemming, motiewe en tematiek van die dekadentisme, daardie karakteristieke soos ons as hedendaagse lesers dit deduktief herken, duidelik en funksioneel verskyn. Na die herlees en struktuuranalise waarvan in paragraaf 3.3.1-3.3.2 verslag gedoen is, kom dit vir my voor of die genoemde tekste die inherente kern verwoord van 'n literêre tendens waarvoor daar nie toe 'n manifes of repertorium bestaan het nie blote navolging of oorskrywing was dit waarskynlik dus nie.

Wat wel waar is, en net so interessant, is dat hierdie betrokke outeurs tog verwante geeste was wat mekaar onderling, of die werk van ander groot dekadentiste geken, gelees, of ten minste van geweet het. Timmermans het onder andere reeds as jong man Maeterlinck, Huysmans en Teirlinck gelees; Van de Woestijne het Teirlinck goed geken en die werk van die Franse Simboliste en dekadentiste "ingeasem" (Rutten, 1958:53, 65, 99, 104). Albei het ook intieme en langdurige kontak met veral Vermeylen en De Bom gehad. Onder die ouer Afrikaanse prosaïste was sowel Marais as Leipoldt baie goed bekend met en uitge- 
sproke bewonderaars van Baudelaire, Maeterlinck, Poe, George Moore, De Quincy, Huysmans en ander dekadentiste. Marais self het rondom die eeuwending hom in Londen in die sfeer van die Engelse fin de siècle ingeburger en daar gewoon en gewerk (Grobbelaar, 1991:151-178).

Dalk is die tyd nou reg vir 'n sistematiese en indringende herevaluasie van bekende outeurs, oeuvres en literêre eras. In die Vlaamse letterkunde veral mag die byeenbring en saamlees van talle, maar verspreide enkeltekste en outeurs 'n ruimer perspektief op die aard en omvang van 'n skynbaar nie-bestaande verskynsel, naamlik die Vlaamse dekadentisme, na vore bring. Om hierdie outeurs en titels wat tans nog op lukrake maar tog byna verleidelike wyse in die bekende literatuurgeskiedenisse slegs vermeld word, gesamentlik te beskou en te interpreteer, lyk my 'n sinvolle en insiggewende taak.

'n Hedendaagse beskouing van Afrikaanse outeurs wat tradisioneel as volksdigters of as spesialiste in ander literêre genres geëvalueer is, bring beslis 'n nuwe, groot waardering vir hulle innoverende en uitsonderlike prosawerk. Vanuit die moderne leser se gesigspunt beskou, kom die dekadentisme voor as veel meer as net 'n blote modegier of 'n noodwendige oorgangsfase na 'n nuwe literêre periode. Soos dit deur uiteenlopende outeurs in verskillende tale en tydperke ontgin is, neem dit ook die funksie aan van 'n asof noodwendige subversie van die heersende en dikwels benouende norm. $\mathrm{Na}$ my mening is vanuit daardie norm, in hierdie geval die Vlaamse en Afrikaanse volkskuns, nie die enigste of 'beste' prosawerk gelewer nie.

Met so ' $n$ herlees en saamlees van ouer en dikwels vergete tekste, beleef die leser opnuut en intens die vitaliteit van die woord. Blykbaar kan die 'ou' boeke nie net deur elke leesgenerasie herlees word nie, maar word dit ook, in 'n mate, herskryf.

\section{Literatuurlys}

Anbeck, Ton 1990. Geschiedenis van de Nederlandse literatuur tussen 1885 en 1985 . Amsterdam : De Arbciderspers.

Castro, Janice 1991. The Simple Life Comes Back. Time, 137(14):44-47. April, 8.

De Cculacr, Josć 1959. Felix Timmemmans. Ontmoetingen. Literaire monograficën. Desclec de Brouwer.

Debbaut, Romain 1989. Het naturalisme in de Nederlandse letteren. Lcuven : Acco.

Deprcz, Ada \& (jobbers, Walter (reds.). 1990. Vaamse literatuur van de negentiende eeuw. Dertien verkenningen. Utrecht : HES.

De Vree, Paul 1933. Over den roman. Kursus gehouden aan de Volksuniversiteit Herman van den Rcck. Jong Dietschland. Studieblad voor Vaamsche cultuur en politiek, 7(23-31):5-56.

Fletcher, 1. (ed.). 1979. Decadence and the 1890's. London : Edward Arnold.

(jilman, R. 1979. Decadence - the Strange Life of an Epithet. London : Secker \& Warburg.

Gijsen, Marnix (s.j.-1940) De literatuur in Zuid-Nederiand seden 1830. Standaard Boekhandel.

Goedegebuure, Jaap 1983. Decadentisme. Omschrijving van een literair-historisch concept. Fonum der Letteren, 24(3) : 161-178, September.

Gocdegebuurc, Jaap 1987. Decadentie en literatuur. Amsterdam : De Arbeiderspers.

Grobbclaar, M. 1991. Die "bose" skoonheid. Verskyningsvonne van estetisisme en dekadensie in die Afrikaanse prosa met toespitsing op die werk van Hennie Aucamp. (Ongcpublisecrde proefskrif (D.Litl et Phil) - Pretoria. Universiteit van Suid-Afrika.)

Grunwald, Henry 1992. The Year 2000. It is the End - or Just the Beginning? Time, 139(13):57-60, March, 30.

Lampo, Hubert 1\%1. Felix Timmemans. Monografieën over Vlaamse letterkunde. Brusscl : Mantcau. Lissens, R.F. 19674. De Vaamse letterkunde van 1780 tot heden. Brussel : Elscvicr. 
Roos, Henriette 1990. Verskyningsvorme van die Simbolisme in die ouer Afrikaanse vertclkuns. Literator, 11(1):13-34, April.

Rutten, M. 1959. Het proza van Karel van de Woestijne. Parys : Les Belles Lettres.

Rutten, Th. 1928. Felix Timmermans. Den Haag : J.B. Wolters.

Teirlinck, Herman 1983 (1909). Het ivoren aapje. Een roman van Brusscls leven. Ansterdam : Querido.

Timmermans, Felix (s.j. - 1910). Schemeringen van den dood. Amsterdam : Kampen \& Zoon.

Timmermans, Felix (s.j. ${ }^{2}$ 1951). Uit mijn rommelkas. Rond het ontstaan van Pallieter" en Het kindeken Jezus in Vlaanderen. Amsterdam : Van Kampen \& Zoon.

Van Buuren, M. 1982. Esthetiscisme. Aanzet tot een definitie van de 'fin-de-siècle' litcratuur. Forum der Letteren, 23(2): 81-96, Junic.

Van de Woestijnc, Karel 1910. Afwijkingen. Bussem : Van Dishoeck. ("Dood van Salomo" (1895), bl. 4148.)

Van de Woestijne, Karel $1917^{2}$ (1908). Janus met het dubbele voorhoofd. Bussem : Van Dishoeck.

Vandevoorde, Hans 1989. Het zieltogen van een ceuw. Over decadentie en neo-decadentic. Yang, 25:151-161.

Van Vlierden, B.F. 1969. Van In 't wonderjaer tot De verwondering. Een poetica van de Vlaamse roman. Antwerpen : De Nederlandsche Boekhandel.

Vergeer, Charles 1990. Toen werden schoot en boezem lekkemij. Erotiek van de Tachtigers.

Amsterdam : Thomas Rap.

Vervliet, Raymond 1982. De literaire manifesten van het fin de siecle in de Zuid-Nederlandse periodieken 1878-1914. 2 Vol. Gent : Rijksuniversitcit.

Vlasselaers, J. 1985. Literair bewustzijn in Vaanderen 1840-1893. Een codereconstructic. Leuven : Universitaire Pers.

\section{Universiteit van Suid-Afrika}

